\section{Performance prediction of hydraulic breakers in excavation of a rock mass}

Rudarsko-geološko-naftni zbornik

(The Mining-Geology-Petroleum Engineering Bulletin) UDC: 622.2

DOI: $10.17794 / \operatorname{rgn} .2021 .4 .9$

Original scientific paper

\author{
Mohamed Ismael; Khaled Abdelghafar; Mohamed Sholqamy; Mohamed Elkarmoty \\ Cairo University, Faculty of Engineering, Department of Mining, Petroleum, and Metallurgical Engineering, 1 Gamaa Street, 12613, \\ Giza, Egypt
}

\begin{abstract}
The demand for the usage of hydraulic rock breakers in excavating rock masses has increased recently for environmental and economic reasons. The conventional method (i.e., drill and blasting technique) has many restrictions due to environmental aspects. In this paper, we propose a methodology for the prediction of the performance of hydraulic rock breakers in the excavation of a rock mass. The case study area is located in Northwest Egypt on the shoreline of the Mediterranean Sea. Extensive site investigation was implemented using exploration boreholes showing that the majority of the site is limestone with lenses of sands. Based on the collected rock properties, mapping of both the rock quality (RQD) and the uniaxial compressive strength (UCS) for the rock mass was conducted. Such mapping of the mechanical properties helps in the zoning of a rock mass and grouping the similar rock zones of nearly matched properties. Due to economic and machinery availability concerns, this study focuses on very small, small, and medium capacity hydraulic breakers. For each type of rock breaker, calculations of the net breaking rate (NBR) are implemented for each group of the rock with similar properties. The challenge of this methodology is that the excavation of the rock mass shall be implemented in a very limited time frame (only one year $\approx 300$ workdays). Therefore, two scenarios of light-duty and medium rock breakers are applied providing the number of machines required with specifications and working days. The first scenario is assigned to medium duty machines, while the second scenario concerns very small to small rock breakers. In general, such a sequence could be adopted for other cases with different rock mass properties, hydraulic breakers specifications and any desired time frame.
\end{abstract}

Keywords:

Hydraulic breakers; rock breaking; breaking rate; rock mass properties

\section{Introduction}

A rock mass is composed of a combination of rock materials and a network of discontinuities. Rock masses vary in quality from very poor quality to excellent according to numerous factors, depending on the strength of the intact rock, the intensity and the condition of the discontinuities and the ground water conditions (Jaeger \& Cook, 2007). Explosive and nonexplosive methods (i.e., the mechanical methods) are two different widely used methodologies to disintegrate a rock mass into smaller pieces (Ocak \& Bilgin, 2010). The method selection is made according to the rock mass properties and the site characteristics.

On one hand, the drill and blasting method is widely used for rock breaking due to its high efficiency and relative medium cost (Škrlec et al., 2014; Ocak and Bilgin, 2010; Tsiambaos and Saroglou, 2010). Aside from its efficiency, this method produces several hazard-

Corresponding author: Mohamed Elkarmoty

mohamed.elkarmoty@cu.edu.eg ous impacts such as high vibration waves, fly rock, dust, toxic gases, noise, so that there are firm environmental restrictions for applying the drill and blasting method (Sobko et al, 2019). In many cases, blasting is not allowed inside urban regions due to environmental or security restrictions (Ocak and Bilgin, 2010). Blasting methods were widely used for hard rock breaking, while the usage of mechanical breaking methods for hard rocks has recently increased mainly in fractured formations (Ocak et al., 2018). Moreover, using mechanical breaking methods involves lower capital costs, higher safety, a cleaner environment and higher strata control than blasting methods (Tumac and Hojjati, 2016).

There are several nonexplosive or mechanical methods such as hydraulic breaking, ripping, and digging. The application of these methods is mainly dependent on the geo-mechanical properties of the rock medium, such as Uniaxial Compressive Strength (UCS), Rock Mass Rating (RMR), Rock Quality Designation (RQD), and Geological Strength Index (GSI) (Kujundžić \& Vrkljan, 2014; Aksoy, 2009; Iphar, 2012; Tsiambaos \& Saroglou, 2010). In general, ripping and digging are 
utilized for a highly fractured rock mass (Sobko et al., 2019). The focus of this paper is on hydraulic rock breakers.

The selection of a hydraulic breaking machine depends on the rock type, the intact rock strength, the type of machinery, chisel and its specifications. Therefore, intensive geotechnical studies and ground investigation are required to determine the rock properties to evaluate the appropriate breaker machine for breakage. The choice of the breaking machine has an economic factor besides the previous mentioned factors. Hammer-type breakers are more convenient and economical for soft rocks due to their lower mechanical properties (Aksoy, 2009), while roadheaders show higher bit wear, lower performance, and have a lower life-span (Biligan et al., 1996 ; Ocak et al., 2018).

Hydraulic rock breakers have two main components: the carrier and the hammer. A balance between the carrier and the hammer weights and the length of the arm shall be sustained to avoid a deficiency in the hydraulic rock breaker. The main factor of a hydraulic breaker's efficiency is the stability, and therefore better rock excavation is possible when the balance between the carrier weight (Wc) and hammer weight (Wh) is stable, as shown in Figure 1. In Equation 1, the moments due to either the carrier weight or hammer weight should follow a certain value (Ocak et al., 2018; Ocak \& Bilgin, 2010). The given values, i.e.: 0.3 to 0.5 , are the balance ratios which reflect the interaction between the hammer shock (impact) and the carrier absorption of the resulted shake (Ocak et al., 2018). For instance, the balance ratio is defined as in Equation 1 to ensure the production of an acceptable impact energy from the hammer without excessive shaking or great reflected forces on the carrier itself (Anderson and Papineau, 1989).

$$
0.30<\frac{A * W h}{B * W c}<0.50
$$

The hammer tool (i.e., the chisel) is provided in different shapes, such as the wedge, the moil, the conical,

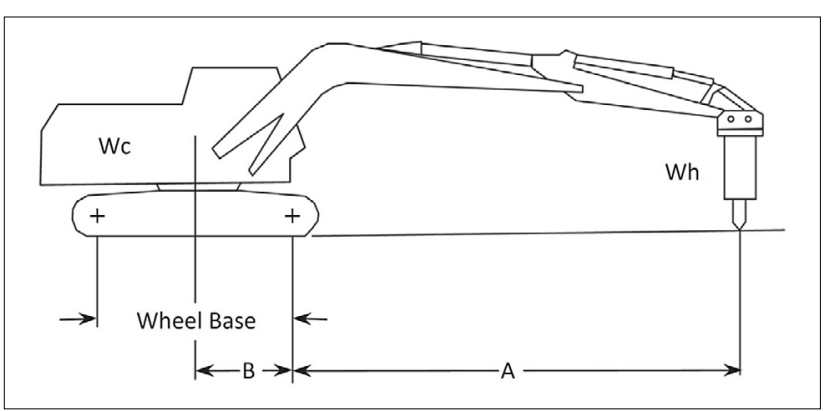

Figure 1: Hydraulic rock breaker schematic showing the factors of the breaker's balance, where: Wc is the carrier weight, $\mathrm{Wh}$ is the hammer weight, $\mathrm{A}$ is the maximum reach of the carrier and $B$ is the half length of wheel base (Ocak et al., 2018). and the blunt (Pandey et al., 2020). On the other hand, the angle of the impact of the chisel greatly affects the excavatability of the rock mass. For example, an increase in impact angle leads to an increase in the breaking energy (Aksoy et al., 2013). The type of chisel affects the production rate of the machine. In general, the selection of the chisel type is combined with the targeted engineering application and the rock type (Pandey et al., 2020). Firstly, the wedge chisel provides the best splitting power for cracked and fissured rock masses or reinforced concrete, while the moil and cone types are perfect for hard rocks and concrete where penetrative breaking is required. The conical point chisel works with non-abrasive soft rocks. Lastly, the blunt type is used for hard rocks with low abrasiveness.

In addition to the chisel type, hydraulic breakers are classified according to their sizes, as shown in Table 1. They vary in size from very small- to high-capacity breakers (heavy duty) with different production rates. For small breakers, the operational pressure is less than $14 \mathrm{MPa}$, the impact rate is lower than 400 blows per minute (bpm) and the impact energy emitted from the chisel does not exceed 1000 Joules (Pandey et al., 2020). On the other hand, high-capacity breakers (heavy duty) work with an operational pressure over $18 \mathrm{MPa}$ and an impact rate higher than $700 \mathrm{bpm}$, while the impact energy exceeds 9000 Joules (Aksoy, 2014). The medium-capacity breakers are considered to be in between the previous mentioned specifications. The selection of the size depends on many technical and economic factors, as well as the rock mass quality. For instance, from a geomechanical point of view, small or medium breakers would be suitable for a soft rock mass with an intact rock strength up to $20 \mathrm{MPa}$ according the ISRM (Kanji, 2014) (RQD is very poor to poor), while a highcapacity breaker would be used for effective breaking of a hard rock mass with an intact rock strength of up to 90 MPa (RQD is good to excellent) (Aksoy, 2014).

Table 1: Classification of the size of the hydraulic rock breakers, after (Pandey et al., 2020)

\begin{tabular}{|l|l|l|}
\hline Parameters & $\begin{array}{l}\text { Small } \\
\text { breakers }\end{array}$ & $\begin{array}{l}\text { large } \\
\text { breakers }\end{array}$ \\
\hline Operational pressure, MPa & $<14$ & $>18$ \\
\hline Impact rate, Blow/minutes & 400 & 700 \\
\hline Impact energy, Joules & $<1000$ & $>9000$ \\
\hline
\end{tabular}

On the economic side, accomplishing the excavation of a rock mass as fast as possible would be the best choice for a given engineering project (Aksoy, 2014). However, this methodology will lead to use bigger hydraulic rock breakers with a sometimes larger number of machines used for a project. Bigger breakers require higher running costs for both maintenance and energy (fuel). Such running costs could maximize the total cost of the project in general, nevertheless, such a choice 
could shorten the project schedule. Additionally, an increase in the number of machines or the size of the breakers would require special safety regulations arranging the entire project. Therefore, it is always a critical matter of optimization between the economic consideration and the selection of suitable hydraulic breakers.

Several studies discussed the relation between geomechanical parameters and the selection of the excavation method. Rock mass quality is measured in terms of Uniaxial Compressive Strength (UCS), it is suggested that mechanical excavation is applicable when the UCS value is lower than $70 \mathrm{MPa}$ (Tsiambaos \& Saroglou, 2010), while another opinion stated that the excavation using breakers may be acceptable with a UCS value up to $90 \mathrm{MPa}$ (Sobko et al., 2019). To produce a breakability chart for rock masses, Aksoy used rock parameters such as the rock structure index (RSI) and volumetric joint $\left(y_{v}\right)$ as defining parameters for rock mass quality (Aksoy, 2014). Moreover, Rock Mass Designation (RQD), Brazilian tensile strength, hardness measured with a Schmidt hammer, Cerchar abrasivity index (CAI), and UCS are used to predict the performance of rock breakers (Kujundžić et al., 2008; Tumac \& Hojjati, 2016; Sobko et al., 2019).

The paper aims at the presentation of a methodology for the prediction of the performance of rock hydraulic breakers. According to literature, it is very important to select the suitable breaker for a given rock mass. However, there is no given methodology for estimating the adequate number of breakers as well as the types of breakers to be used. In general, excavation using a rock breaker has performance limitations in a restricted time frame. Therefore, this paper adjusted the methodologies from literature to estimate both the type and number of rock breakers for the excavation of a rock mass in a defined time frame. The case study is located on the north coast of Egypt where the site is extensively investigated, and rock parameters are obtained from site observations and lab testing. These parameters are later used in the calculation stages. The methodology proposed by the paper could be modified for different scenarios depend- ing on the types of the selected rock breakers and the time frame given for the excavation. This paper introduces two scenarios for medium and light-duty rock breakers.

\section{Site characteristics}

The studied region lies near El-Dabaa City, Northwest of Egypt, North Coast along the south Mediterranean coastal line (see Figure 2). The region is being subjected to huge development plans to establish new urban settlements including tourism villages and residential clusters. A study was performed in this region as it is formed of topographically rough terrain that needs excavation and smoothing for construction purposes. The climate of this region is semi-arid to arid, which has a great influence on the geological formation of the re-

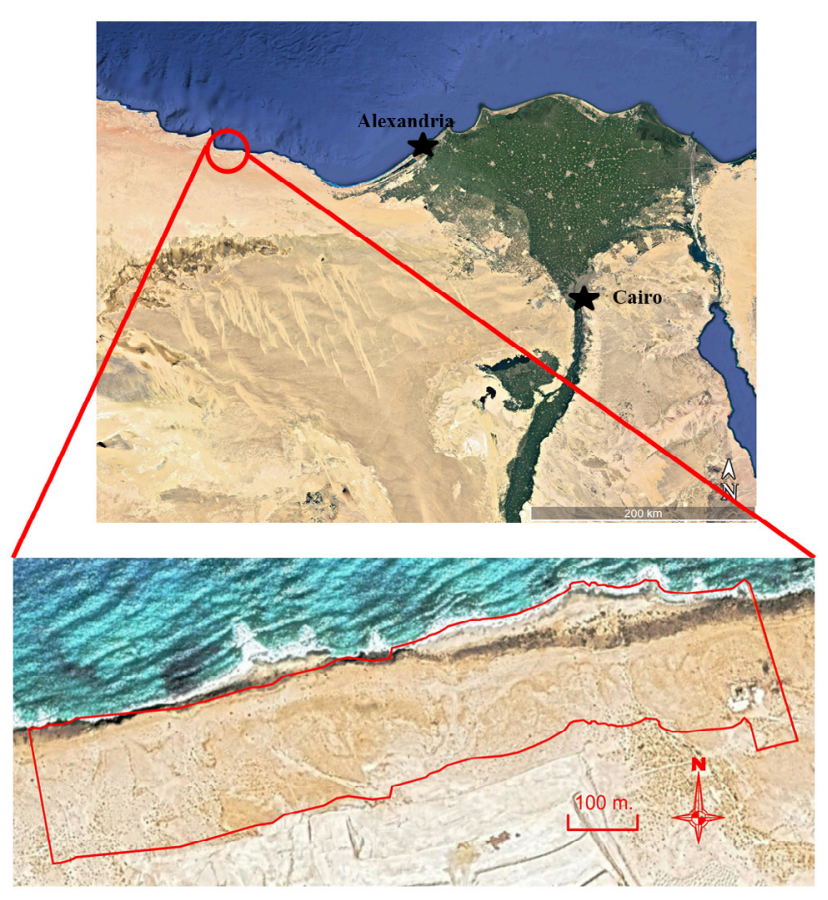

Figure 2: Satellite view of the site

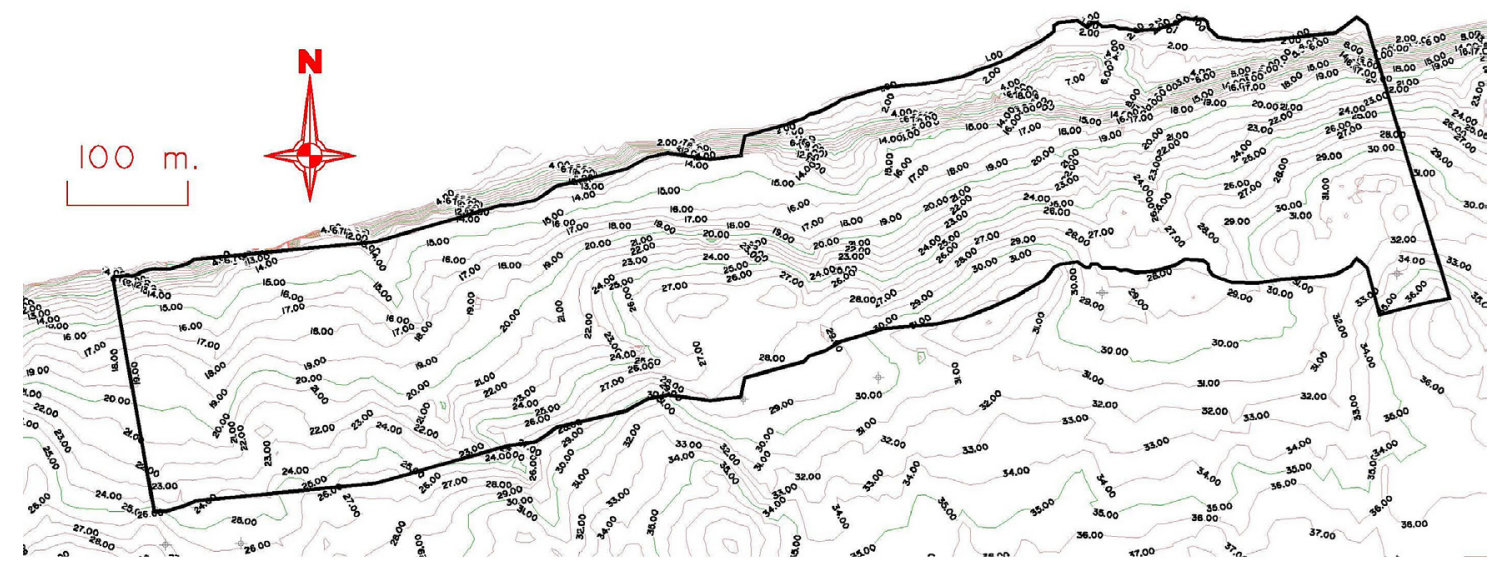

Figure 3: Contour map of the study area, the polygon represents the study area. 


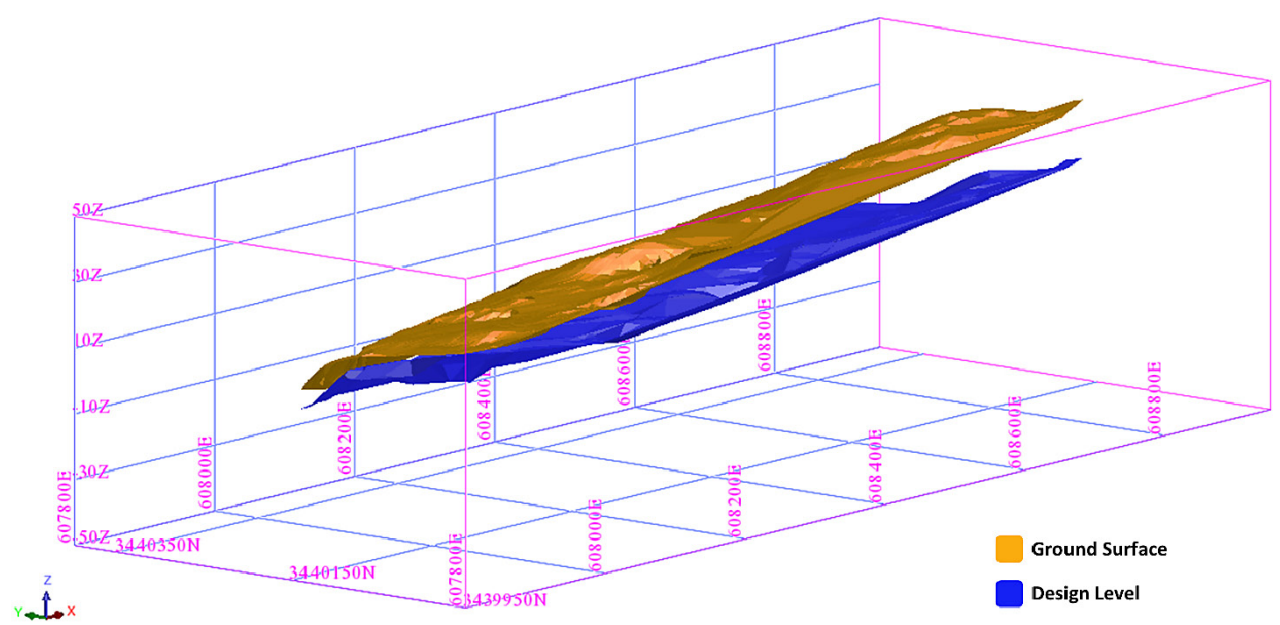

Figure 4: Three-dimensional ground model vs design level

gion. The studied area represents the shoreline with an extension of $1110.0 \mathrm{~m}$ along the sea line and 200.0 to $235.0 \mathrm{~m}$ into the land. The topography of the studied area ranges from 0.0 to $33.0 \mathrm{MSL}$ where the terrain is very steep near the shoreline (see Figure 3).

The site is composed of a sedimentary succession from Tertiary to Quaternary ages (Eissa et al., 2018). The site is mainly a coastal plain which consists of oolitic carbonate rocks, such as limestone and sand dunes. The formation of this region is near the Alexandria Formation in which the oolitic limestone formation was deposited from middle to late Pleistocene (El-Asmar \& Wood, 2000). The limestone formation is planar/tabular cross stratification and a weak to highly cemented rock unit. The thickness of the formation is variable. However, in this region, the defined thickness is $40.0-60.0$ $\mathrm{m}$, which is a moderate size.

\section{Methods}

\subsection{Site Investigation}

It is necessary to excavate the rocky terrain from its current level (see Figure 3) to reach an overall elevation to about 0.0 to $4.0 \mathrm{~m} \mathrm{MSL}$. The shaping of the terrain shall be done using mechanical breakers instead of the drill and blasting method due to environmental concerns. The calculations show that there is a need to cut nearly 2,880,839.49 cubic meters (calculated using CAD Civil 3D) to reach the required design level (see Figure 4 and Table 2). No swell of the excavated material is assumed, so that the cut and fill factors are assigned to equal one. The excavation of this volume of rocks entails a huge amount of work for breaking machines, which depends on the rock properties and machine types.

As shown in Figure 5, a total of 34 boreholes were executed as a part of the investigation of the site. 28 boreholes are located in the area of the study (the volume), the codes of those boreholes are given in Table 3.
Table 2: Cut and Fill volumes of the ground

\begin{tabular}{|l|l|l|l|}
\hline \multicolumn{4}{|l|}{ Volume summary } \\
\hline Cut factor & Fill factor & 2D Area, $\mathrm{m}^{2}$ & Volume Net, $\mathrm{m}^{3}$ \\
\hline 1.00 & 1.00 & 210077.14 & 2880839.49 (Cut) \\
\hline
\end{tabular}

The UCS values have been obtained for only 15 boreholes, while the rest of the boreholes' values have been reasonably calculated using classical interpolation (see Table 3). The RQD is calculated at each $1.00 \mathrm{~m}$ depth for each borehole. The entire study area is divided into smaller zones (polygons) surrounding each borehole and passing through the midpoint between every two successive boreholes (see Figure 5). Such sub-dividing helps later in the characterization of the study area. The UCS and RQD of the borehole are assumed to be representative of each subdivided zone (i.e., the polygon). This is also considered as a kind of restriction for the calculations due to the limited sample size. The given data shows that the range of the UCS values lies between 2.01 $\mathrm{MPa}$ (in $\mathrm{BH} 32$ ) and 25.95 $\mathrm{MPa}$ (in $\mathrm{BH} 24$ ), which can be classified between very soft to low strength soft rock according to (Kanji, 2014) (see Figure 6). The 3D geological section shown in Figure 7 indicates that the stratification is mainly formed of limestone with different values of RQD at each depth interlayered with loose to very dense sand lenses. Consequently, the assessment of the mechanical breakers shall be conducted based on the gathered information from the site investigation.

\subsection{Productivity assessment}

The productivity of the hydraulic breakers depends on geomechanical properties and technical specifications of the machines (Aksoy, 2013):

- UCS - tensile strength - hardness - abrasiveness elasticity, plasticity, brittleness - rock mass properties (bedding planes, joints, fractures, fault zones);

- Available power, working pressure, oil flow rate, impact rate, machine weight and thrust. 


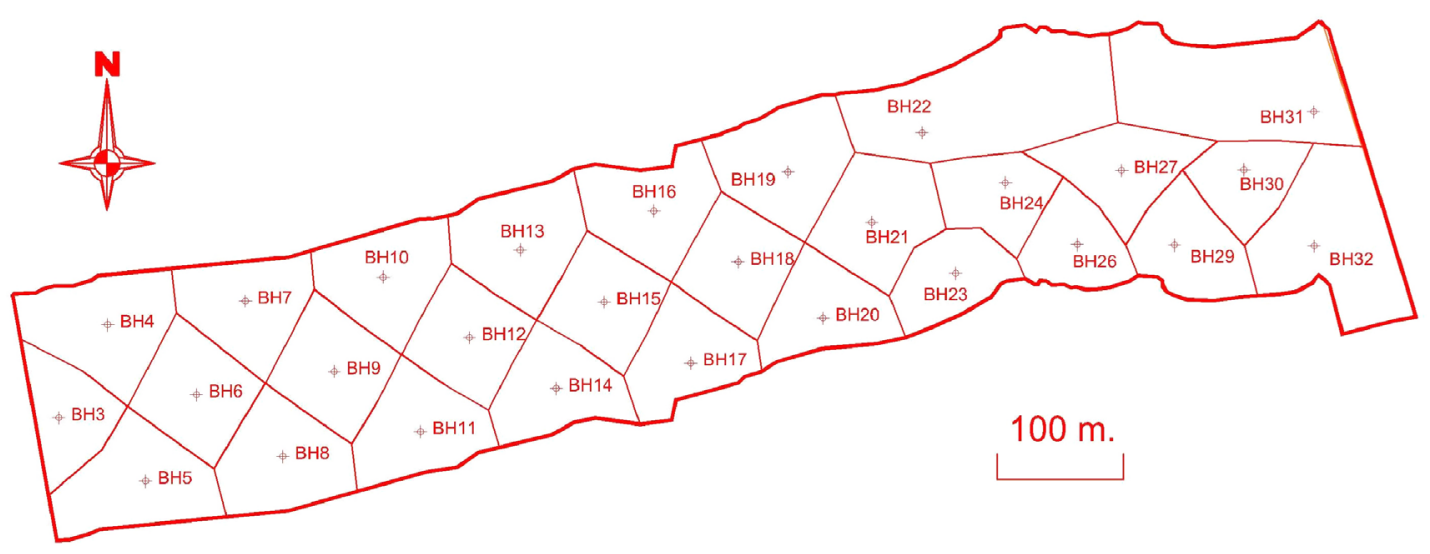

Figure 5: Locations of boreholes and the divided zones

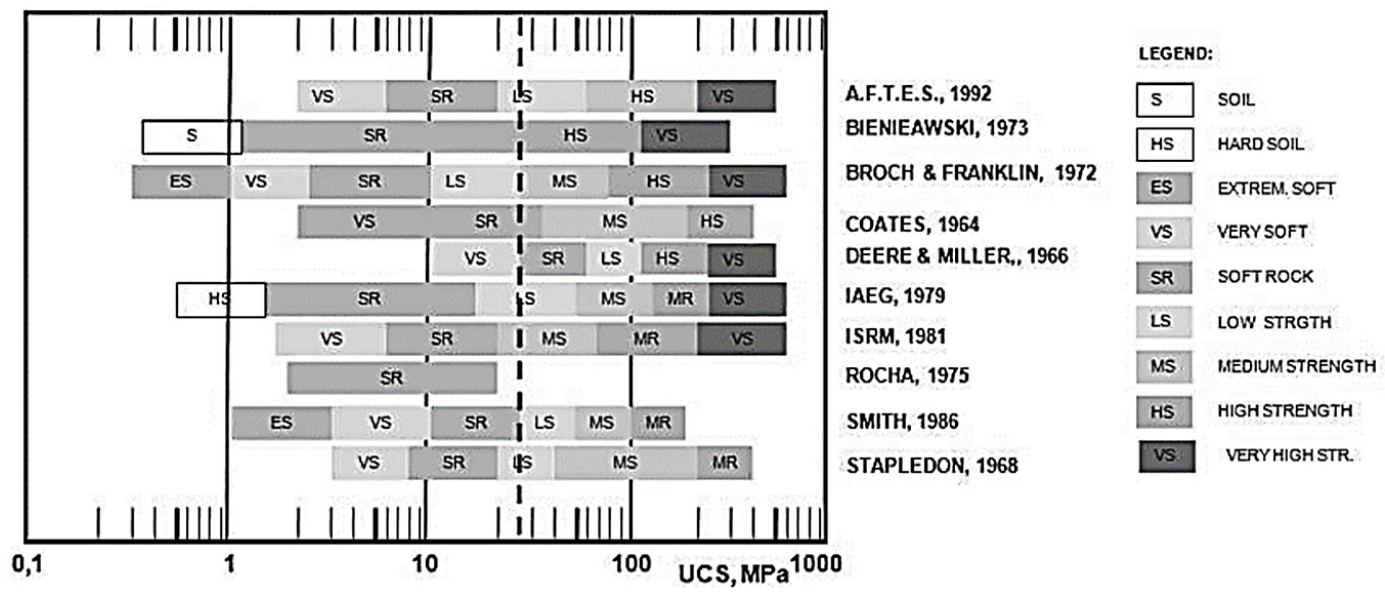

Figure 6: Classification of geomaterials of UCS (from Kanji, 2014)

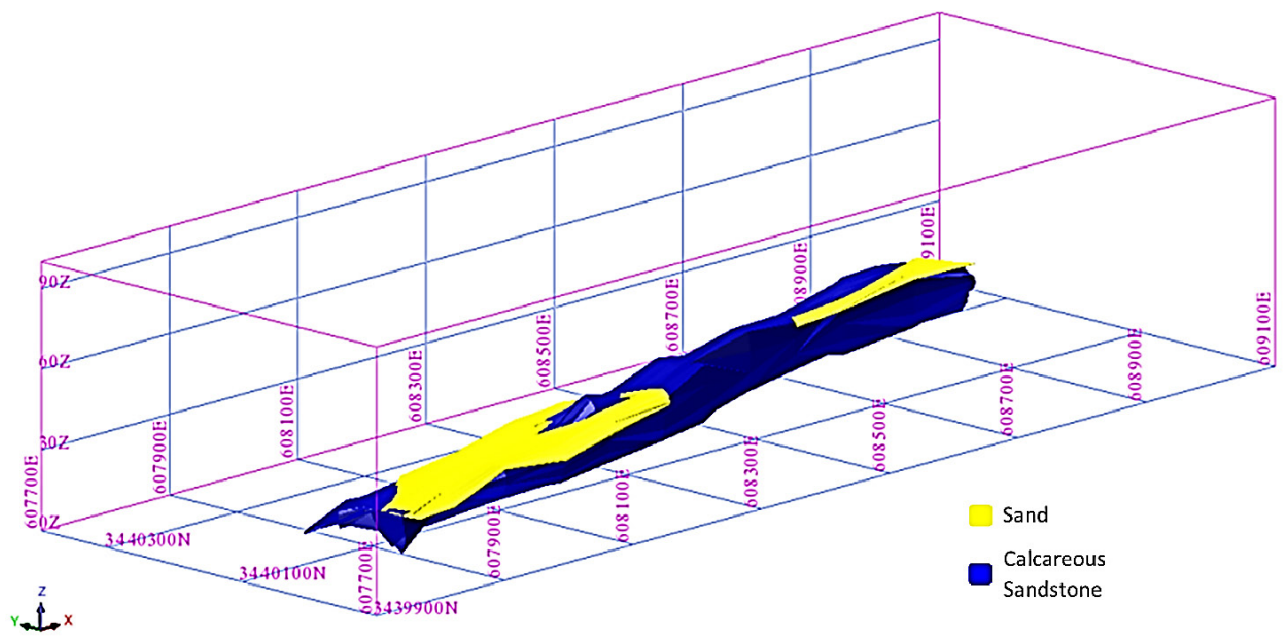

Figure 7: Three-dimensional geological section of the area

The breaking rate or the productivity is the most reliable factor determining the duration which is taken for the rock mass excavation in the first place. These parameters are used in the selection of the optimum size of rock breakers to fulfil the objective or the targeted time frame. The Net Breaking Rate (NBR) is the rate which could be produced from the machinery computed power and the so-called Rock Mass Cuttability Index (RMCI). NBR is calculated based on the following formula Equation 2 (Biligan et al. 1996; Ocak et al., 2018): 
Table 3: Volume and average mechanical properties of each borehole

\begin{tabular}{|c|c|c|c|c|c|c|c|}
\hline $\begin{array}{l}\text { Borehole } \\
\text { zone }\end{array}$ & $\begin{array}{l}\text { UCS, } \\
\mathrm{MPa}\end{array}$ & $\begin{array}{l}\text { Average } \\
\text { RQD, \% }\end{array}$ & $\begin{array}{l}\text { Volume of zone, } \\
\mathrm{m}^{3}\end{array}$ & Borehole & $\begin{array}{l}\text { UCS, } \\
\mathrm{MPa}\end{array}$ & $\begin{array}{l}\text { Average } \\
\text { RQD, \% }\end{array}$ & $\begin{array}{l}\text { Volume of zone, } \\
\mathrm{m}^{3}\end{array}$ \\
\hline BH3* & 4.29 & 37.50 & 17118.95 & BH18* & 10.83 & 20.5 & 108272.32 \\
\hline $\mathrm{BH} 4 *$ & 9.99 & 3.33 & 58198.25 & BH19 & 8.94 & 27.92 & 65933.99 \\
\hline BH5* & 10.48 & 1.66 & 34629.63 & BH20 & 2.32 & 17.00 & 125770.54 \\
\hline BH6 & 16.60 & 33.60 & 84189.87 & $\mathrm{BH} 21$ & 9.59 & 41.32 & 120075.46 \\
\hline BH7 & 9.08 & 36.67 & 97545.51 & BH22* & 17.77 & 22.5 & 103436.42 \\
\hline BH8* & 10.55 & 19.23 & 71734.59 & BH23* & 7.89 & 29.42 & 110492.05 \\
\hline $\mathrm{BH} 9 *$ & 10.34 & 27.78 & 88107.93 & $\mathrm{BH} 24$ & 25.95 & 35.72 & 92974.50 \\
\hline BH10 & 10.98 & 30.89 & 99861.89 & $\mathrm{BH} 25$ & Missed data & & \\
\hline BH11 & 4.70 & 23.23 & 89656.37 & BH26 & 6.19 & 25.24 & 92002.39 \\
\hline BH12* & 7.44 & 23.42 & 99019.42 & $\mathrm{BH} 27$ & 10.71 & 38.86 & 115030.24 \\
\hline BH13* & 13.40 & 30.53 & 121154.70 & $\mathrm{BH} 28$ & Missed data & & \\
\hline BH14* & 5.43 & 25.00 & 112252.05 & BH29* & 4.1 & 28.26 & 118141.12 \\
\hline BH15 & 4.53 & 32.00 & 124485.93 & BH30 & 3.43 & 27.40 & 102491.49 \\
\hline BH16 & 19.34 & 32.94 & 98633.09 & BH31 & 4.52 & 37.31 & 176457.03 \\
\hline BH17* & 3.43 & 20.00 & 119408.84 & BH32 & 2.01 & 14.13 & 233764.92 \\
\hline
\end{tabular}

*The UCS values were not obtained for those BHs. The UCS values were reasonably estimated using the means of extrapolation (the inverse distance method).

$$
N B R=4.24 \times P \times R M C I^{-0.567}
$$

Where:

- NBR is the Net Breaking Rate in $\mathrm{m}^{3} / \mathrm{h}$,

- $P$ is the power of the hydraulic breaker in horsepower,

- $R M C I$ is Rock Mass Cuttability Index which is computed as in Equation 3.

$$
R M C I=U C S *(\mathrm{RQD} / 100)^{2 / 3}
$$

Where:

- UCS is the Uniaxial Compressive Strength in MPa, and

- RQD is the rock Quality Designation in \%.

Moreover, the quality and condition of the available machinery shall be justified. Therefore, an $85 \%$ efficiency of the machinery during the calculations of the machine power shall be assumed. The power of the machine in horsepower is computed as in Equation 4.

$$
\mathrm{P}=1714 \times 0.85 \times q_{0} \times \sigma_{\text {oil }}
$$

Where:

- $q_{0}$ is the Oil flow rate in gallon per minute [gpm], and

- $\sigma_{\text {oil }}$ is the Operating oil pressure in [Psi].

The efficiency and the performance of the rock breakers depend on the detailed geotechnical data collected from the site, i.e., the discontinuity intensity and the strength of the intact rock. In this context, mapping of both the RQD and the UCS are implemented to establish

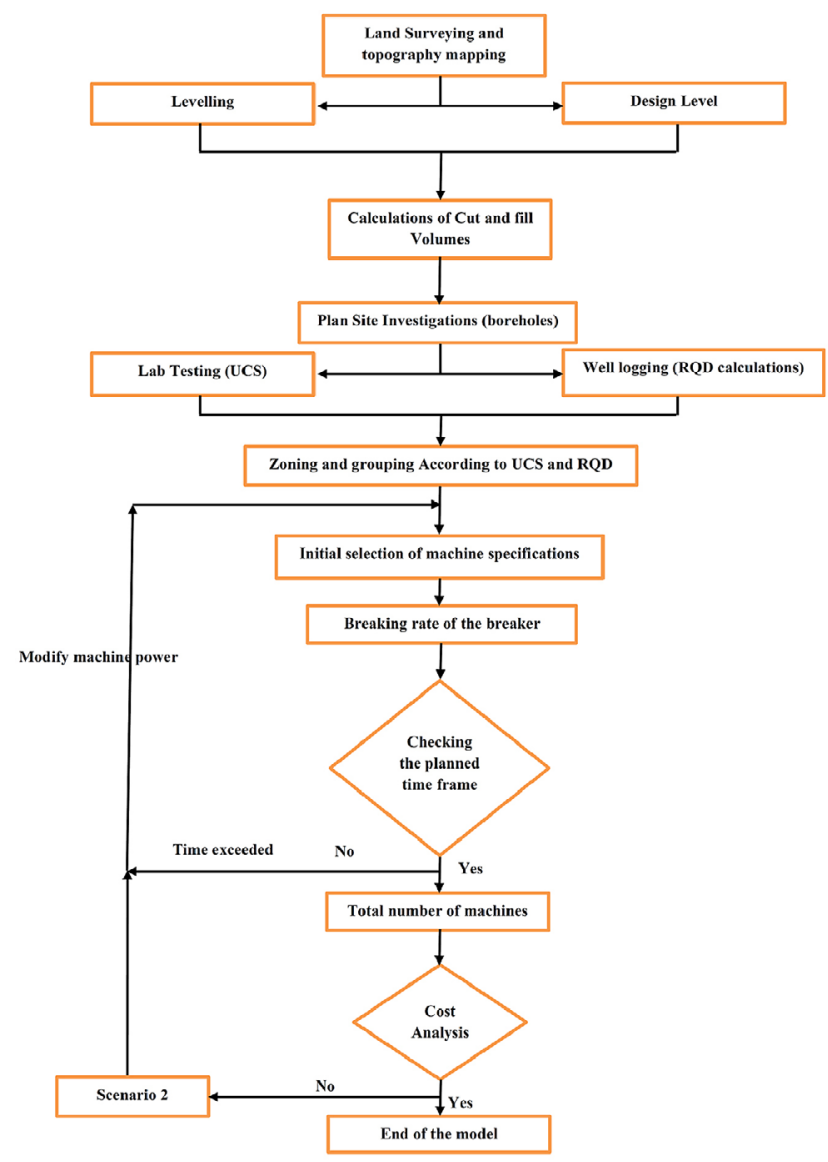

Figure 8: Flowchart of the proposed methodology for rock hydraulic breaker performance prediction 
a proper classification of the rock mass. Then, the rock mass is divided into groups of similar properties and according to the classification.

Based on the grouping of the rock mass, the number of machines (breakers) could be simply calculated. First, the study focuses on the small to medium rock breakers for which the horsepower is calculated as in Equation 4. Secondly, the challenge of this time is that the removal of such rock mass volume shall be done in a limited time (less than one year, about 300 working days). Then, the production rate of breakers is computed based on the allowable time frame and the zones volume. Changing the number of breakers or their specifications can lead to different scenarios in which selection of the best one is a matter of machine availability and economic factors. The proposed methodology is illustrated in Figure 8.

\section{Results}

The zoning of the polygons by using the values of both the UCS and the RQD is created for the area of the study (see Figure 9 and Figure 10). Such zoning is helpful to mark the differences between the rock properties along the rock mass. The figures are built on data from Figure 5 and Table 3. Blocky, very blocky, and seamy structures of a rock mass would be suitable to be excavated using hydraulic breakers (Tsiambaos \& Saroglou, 2010). Therefore, the parameter defining the intensity of the fractures shall be the first parameter which is RQD. Normally, UCS is the second geomechanical parameter controlling the excavatability of a rock mass. The site's rock mass was accordingly classified into four groups based on the UCS and RQD values in the site (see Table 4). Using this classification, the subdivided zones were grouped as shown in Table 4 and graphically presented in Figure 11. Figures 9, 10 and 11 show that the relatively strong zones (i.e., group 4) to be excavated using the hammer are near the shoreline, at which higher RQD values (35 to $40 \%$ ) and higher UCS value (20 to 30 $\mathrm{MPa})$ were recorded. While the relatively weaker zones are distributed towards the inland (the south side of the site) where the ground is very weathered (i.e., sandy and fractured).

After applying the classification on the defined zones, the calculations of breaking rate are carried out. First, the zones, as defined in Figure 11, are sub-divided into

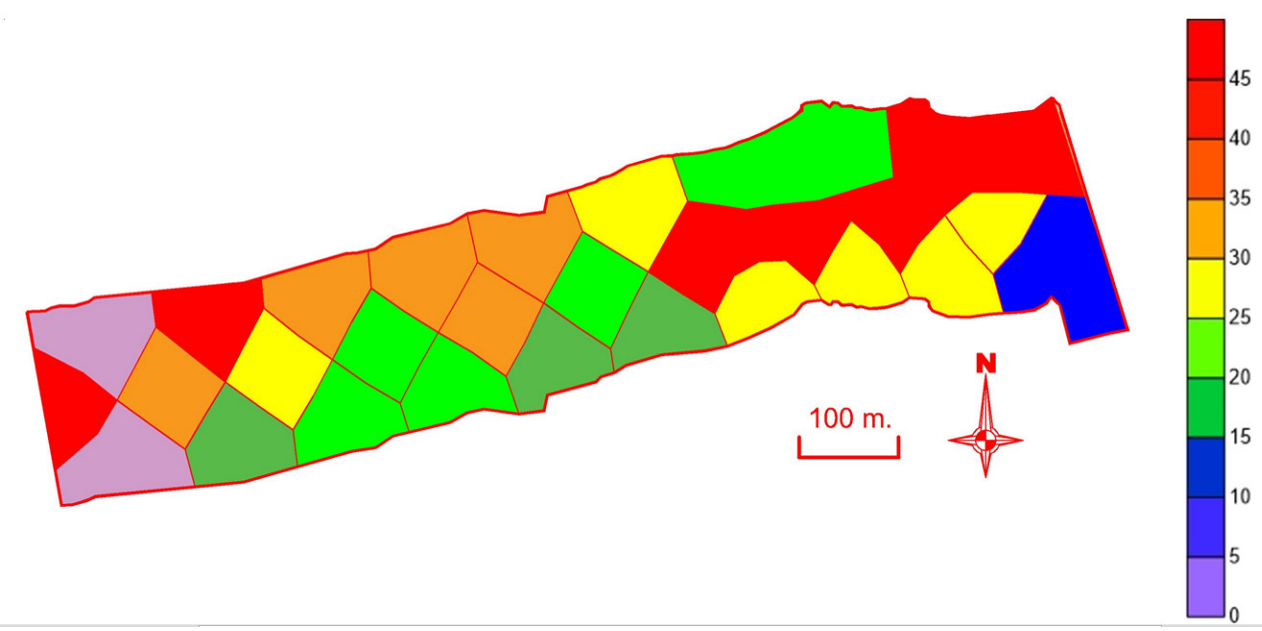

Figure 9: Zoning of the UCS values by the given polygons, the given values in the legend of UCS are in MPa.

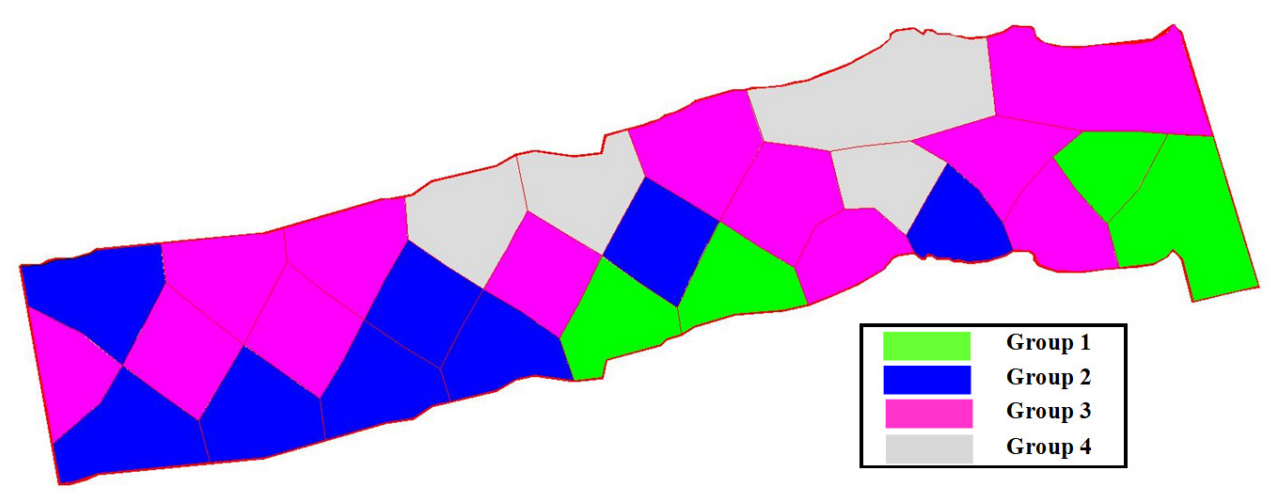

Figure 10: Zoning of the RQD values by the given polygons, the given values in the legend of RQD are in \%. 
four groups. The volumes of each group have been calculated according to the current terrain level and the targeted design level (see Table 4). By assigning the breaker specifications, the horsepower is calculated (see Equation 4) and therefore the NBR is computed for each group (see Equation 2). Generally, the NBR is calculated as a unit of volume per hour which could be simply, knowing both the volume of the rock mass and the number of working hours per day, converted into workdays required to remove the targeted group using the assigned rock hydraulic breaker.

Finally, the number of the required rock breaker machines is estimated based on the total days of the entire process as 300 workdays. This is applied for different groups and different machinery to determine the required duration for the breakage process. In this context, two different scenarios are applied to determine the number and size of the required hydraulic breakers. These scenarios are considering the medium and light

Table 4: Classification of zones into groups according to UCS and RQD

\begin{tabular}{|l|l|l|l|}
\hline Group & Range of UCS & RQD & Description, after Kanji (2014) \\
\hline Group 1 & $0-3.5 \mathrm{MPa}$ & $<25 \%$ & Very soft rock- poor quality \\
\hline Group 2 & $3.5-12.5 \mathrm{MPa}$ & $<25 \%$ & Very soft-soft rock \\
\hline Group 3 & $3.5-12.5 \mathrm{MPa}$ & $>25 \%$ & $\begin{array}{l}\text { Very soft- soft rock with lower } \\
\text { fractures }\end{array}$ \\
\hline Group 4 & $>12.5 \mathrm{MPa}$ & $>25 \%$ & Soft rock \\
\hline
\end{tabular}

duties hydraulic rock breakers as they are more readily available and could be easily maintained or replaced according to the work conditions.

\subsection{Scenario 1: Medium duty hydraulic rock breakers}

Medium duty hydraulic breakers were applied to demolish the rock mass inside the study area. Hydraulic breakers of this category include a wide range of specifications. Therefore, average values of the medium duty breakers are used. Table 5 shows the specifications of each machine type involved in this study for scenario 1 . Two machine types were assigned: Machine 1A and 2B. From the specifications, 1B has a higher impact energy than 1A. The higher the strength and competency of the rock mass, the stronger the employed machine. Therefore, Machine 1A worked on groups 1 and 2, while machine 1B was employed for the rest. According to Aksoy, 2014, the two types of the medium duty hydraulic breakers used in this scenario are classified as small to medium type.

Based on the proposed methodology, the durations and production rate are calculated in Table 6. Group 3 (soft rock with lower fracture intensity) represents the largest group with total volume of $1217439.97 \mathrm{~m}^{3}$, almost $42 \%$ of the total volume. Both groups 3 and 4 (soft rock with higher competency of rock mass) resemble $56 \%$ of the rock mass which requires 1656 working days in total. In general, an increase in the RQD and/or UCS

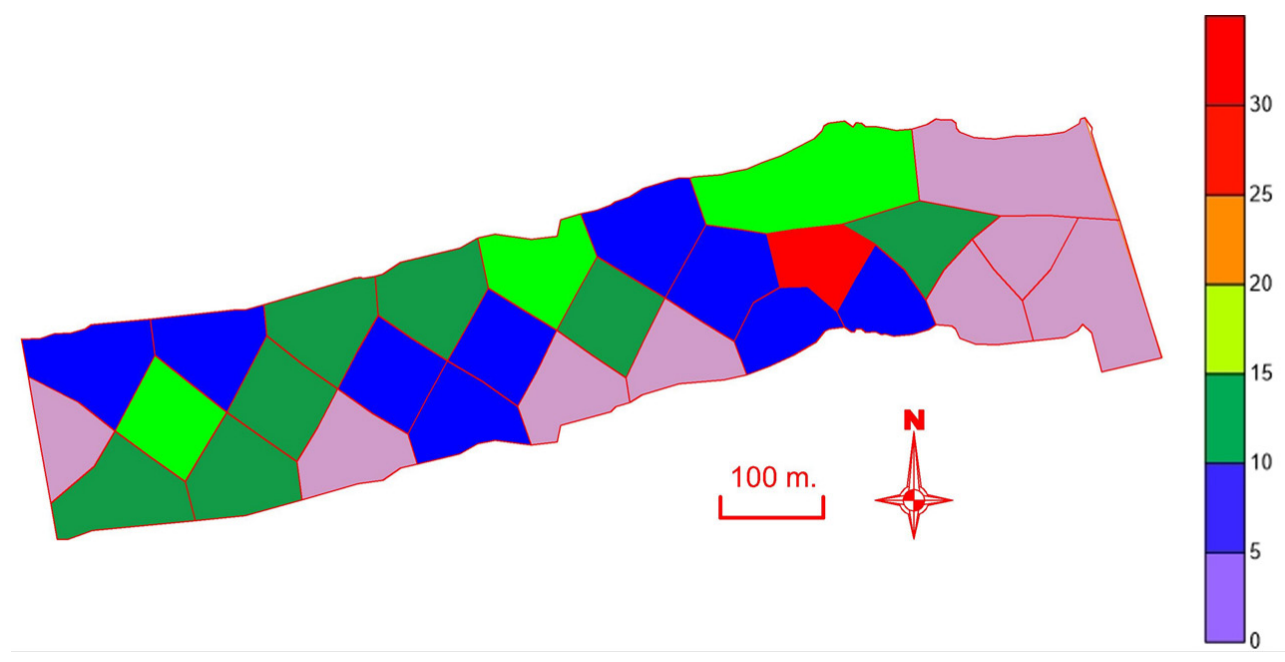

Figure 11: Grouping the zones according to UCS and RQD, see Table 4.

Table 5: Rock breaker types and specifications - scenario 1

\begin{tabular}{|c|c|c|c|c|c|c|c|c|c|}
\hline \multirow{2}{*}{$\begin{array}{l}\text { Machine } \\
\text { Type }\end{array}$} & \multicolumn{3}{|c|}{ Oil flow rate } & \multicolumn{3}{|c|}{ Operating oil pressure } & \multirow{2}{*}{$\begin{array}{l}\text { Impact rate } \\
\text { Blows/min }\end{array}$} & \multirow{2}{*}{$\begin{array}{l}\text { Impact } \\
\text { Energy, } \\
\text { Joule }\end{array}$} & \multirow{2}{*}{$\begin{array}{l}\text { Carrier } \\
\text { Weight } \\
\text { Ton }\end{array}$} \\
\hline & gpm & $\mathrm{L} / \mathrm{m}$ & $\begin{array}{l}\text { Used } \\
\mathrm{gpm} / \mathrm{m} 3 / \mathrm{hr}\end{array}$ & Psi & Bar & \begin{tabular}{|l|} 
Used, \\
Psi/MPa
\end{tabular} & & & \\
\hline Machine 1A & $16-26.5$ & $60-100$ & $23 / 5.22$ & $1849-2276$ & $130-160$ & $2100 / 14.78$ & $400-800$ & 1270 & 10 \\
\hline Machine 1B & $27-40$ & $100-150$ & $30 / 6.82$ & $2276-2560$ & $160-180$ & $2300 / 15.86$ & $350-600$ & 4500 & 20 \\
\hline
\end{tabular}

gpm: gallons per minute, L/m: litre/minute, Psi: lb/in ${ }^{2}$ 
Table 6: Groups of zones and working procedures - scenario 1

\begin{tabular}{|c|c|c|c|c|c|c|c|}
\hline Group & BH & \begin{tabular}{|l} 
Volume, \\
$\mathrm{m}^{3}$
\end{tabular} & Total volume, $\mathrm{m}^{3}$ & Suitable machine & NBR $\mathrm{m}^{3} / \mathrm{h}$ & $\begin{array}{l}\text { Working days } \\
(12 \mathrm{~h} / \text { day })\end{array}$ & Total working days \\
\hline \multirow{4}{*}{ Group 1} & BH 17 & 119408.84 & \multirow{4}{*}{581435.79} & \multirow{4}{*}{ Machine 1A } & 191.57 & 51.94 & \multirow{4}{*}{312} \\
\hline & BH 20 & 125770.54 & & & 254.05 & 41.25 & \\
\hline & BH 30 & 102491.49 & & & 170.88 & 49.98 & \\
\hline & BH 32 & 233764.92 & & & 295.53 & 65.92 & \\
\hline \multirow{8}{*}{ Group 2} & $\mathrm{BH} 4$ & 58198.25 & \multirow{8}{*}{665765.02} & \multirow{8}{*}{ Machine 1A } & 137.93 & 141.24 & \multirow{8}{*}{754} \\
\hline & BH 5 & 34629.63 & & & 174.07 & 16.58 & \\
\hline & $\mathrm{BH} 8$ & 71734.59 & & & 69.18 & 86.41 & \\
\hline & BH 11 & 89656.37 & & & 101.49 & 73.61 & \\
\hline & BH 12 & 99019.42 & & & 78.01 & 105.77 & \\
\hline & BH 14 & 112252.05 & & & 90.96 & 102.84 & \\
\hline & BH 18 & 108272.32 & & & 66.28 & 136.12 & \\
\hline & BH 26 & 92002.39 & & & 84.14 & 91.12 & \\
\hline \multirow{12}{*}{ Group 3} & BH 3 & 17118.95 & \multirow{12}{*}{1217439.97} & \multirow{12}{*}{ Machine 1B } & 127.41 & 11.20 & \multirow{12}{*}{1083} \\
\hline & BH 6 & 84189.87 & & & 62.08 & 113.00 & \\
\hline & BH 7 & 97545.51 & & & 83.99 & 96.78 & \\
\hline & $\mathrm{BH} 9$ & 88107.93 & & & 86.66 & 84.73 & \\
\hline & BH 10 & 99861.89 & & & 80.47 & 103.42 & \\
\hline & BH 15 & 124485.93 & & & 131.17 & 79.09 & \\
\hline & BH 19 & 65933.99 & & & 93.93 & 58.49 & \\
\hline & BH 21 & 120075.46 & & & 77.84 & 128.55 & \\
\hline & BH 23 & 110492.05 & & & 98.85 & 93.14 & \\
\hline & BH 27 & 115030.24 & & & 74.83 & 128.11 & \\
\hline & BH 29 & 118141.12 & & & 145.48 & 67.67 & \\
\hline & BH 31 & 176457.03 & & & 123.93 & 118.65 & \\
\hline \multirow{5}{*}{ Group 4} & BH 13 & 121154.7 & \multirow{5}{*}{416198.71} & \multirow{5}{*}{ Machine 1B } & 72.23 & 139.78 & \multirow{5}{*}{573} \\
\hline & BH 16 & 98633.09 & & & 56.97 & 144.27 & \\
\hline & BH 22 & 103436.42 & & & 69.63 & 123.80 & \\
\hline & BH 24 & 92974.5 & & & 46.77 & 165.66 & \\
\hline & BH 30 & 103416.67 & & & 526.803 & 16.36 & \\
\hline
\end{tabular}

Table 7: Derivation of required number of breakers - scenario 1

\begin{tabular}{|l|l|l|l|l|l|}
\hline Machine Type & Group & $\begin{array}{l}\text { Total working } \\
\text { days }\end{array}$ & $\begin{array}{l}\text { Total working days } \\
\text { / Machine type }\end{array}$ & $\begin{array}{l}\text { No. of machines } \\
\mathbf{( 3 0 0} \text { working days) }\end{array}$ & $\begin{array}{l}\text { Required number } \\
\text { of machines }\end{array}$ \\
\hline Machine 1A & 1 & 312 & 1066 & 3.55 & 4 \\
\hline Machine 1A & 2 & 754 & 1656 & 5.52 & 6 \\
\hline Machine 1B & 3 & 1083 & 573 & 4 &
\end{tabular}

decreases the NBR value and therefore increases the working days.

Based on the Working days calculations in Table 6, the computation of the number of machines for scenario 1 is presented in Table 7. As the total working days for the removal of the rock mass is assumed as 300 working days, 4 1A-type and 6 1B-type hydraulic rock breakers are required. The derivation of the number of the machines does not include the required maintenance or other parallel tasks required for the breakage of the rock mass. 


\subsection{Scenario 2: light duty hydraulic rock breakers}

The light duty hydraulic rock breaker type is the widely available range on the market due to the availa- bility of the spare parts, the simple requirements for the maintenance and they are cheaper. Scenario 2 relies on the light duty hydraulic rock breakers. The specifications of this category are wide range. The average specifica-

Table 8: Rock breaker types and specifications - scenario 2

\begin{tabular}{|c|c|c|c|c|c|c|c|c|c|}
\hline \multirow[b]{2}{*}{ Machine Type } & \multicolumn{3}{|c|}{ Oil flow rate } & \multicolumn{3}{|c|}{ Operating oil pressure } & \multirow{2}{*}{$\begin{array}{l}\text { Impact rate } \\
\text { Blows/min }\end{array}$} & \multirow{2}{*}{$\begin{array}{l}\text { Impact } \\
\text { Energy, } \\
\text { Joule }\end{array}$} & \multirow{2}{*}{$\begin{array}{l}\text { Carrier } \\
\text { Weight } \\
\text { Ton }\end{array}$} \\
\hline & gpm & $\mathrm{L} / \mathrm{m}$ & $\begin{array}{l}\text { Used } \\
\mathrm{gpm} / \mathrm{m}^{3} / \mathrm{hr}\end{array}$ & Psi & Bar & $\begin{array}{l}\text { Used, } \\
\text { Psi/MPa }\end{array}$ & & & \\
\hline Machine 2A & $6.5-13$ & $25-50$ & $10 / 2.27$ & $1280-1707$ & $90-120$ & $1500 / 10.34$ & $600-1100$ & 320 & 3 \\
\hline Machine 2B & $13-24$ & $50-90$ & $20 / 4.54$ & $1707-2134$ & $120-150$ & $1800 / 12.41$ & $400-800$ & 700 & 7 \\
\hline Machine 2C & $16-26.5$ & $60-100$ & $20 / 4.5$ & $1849-2276$ & $130-160$ & $2000 / 13.79$ & $400-800$ & 1270 & 10 \\
\hline Machine 2D & $21-29$ & $80-110$ & $25 / 5.68$ & $2134-2481$ & $150-170$ & $2200 / 15.17$ & $350-700$ & 2000 & 14 \\
\hline
\end{tabular}

gpm: gallons per minute, L/m: litre/minute, Psi: $l b /$ in $^{2}$

Table 9: Groups of zones and working procedures - scenario 2

\begin{tabular}{|c|c|c|c|c|c|c|c|}
\hline Group & BH & \begin{tabular}{|l|} 
Volume, \\
$\mathrm{m}^{3}$
\end{tabular} & Total volume, $\mathrm{m}^{3}$ & Suitable machine & NBR $\mathrm{m}^{3} / \mathrm{h}$ & $\begin{array}{l}\text { Working days } \\
(12 \mathrm{~h} / \text { day })\end{array}$ & Total working days \\
\hline \multirow{4}{*}{ Group 1} & BH 17 & 119408.84 & \multirow{4}{*}{581435.79} & \multirow{4}{*}{ Machine 2A } & 39.91 & 249.33 & \multirow{4}{*}{1004} \\
\hline & BH 20 & 125770.54 & & & 52.93 & 198.02 & \\
\hline & BH 30 & 102491.49 & & & 61.57 & 316.40 & \\
\hline & BH 32 & 233764.92 & & & 35.60 & 239.91 & \\
\hline \multirow{8}{*}{ Group 2} & BH 4 & 58198.25 & \multirow{8}{*}{665765.02} & \multirow{8}{*}{ Machine 2B } & 102.80 & 189.49 & \multirow{8}{*}{1011} \\
\hline & BH 5 & 34629.63 & & & 129.74 & 22.24 & \\
\hline & BH 8 & 71734.59 & & & 51.56 & 115.93 & \\
\hline & BH 11 & 89656.37 & & & 75.65 & 98.77 & \\
\hline & BH 12 & 99019.42 & & & 58.15 & 141.91 & \\
\hline & BH 14 & 112252.05 & & & 67.79 & 137.98 & \\
\hline & BH 18 & 108272.32 & & & 49.40 & 182.63 & \\
\hline & BH 26 & 92002.39 & & & 62.71 & 122.25 & \\
\hline \multirow{12}{*}{ Group 3} & BH 3 & 17118.95 & \multirow{12}{*}{1217439.97} & \multirow{12}{*}{ Machine $2 \mathrm{C}$} & 73.86 & 19.31 & \multirow{12}{*}{1868} \\
\hline & BH 6 & 84189.87 & & & 35.99 & 194.93 & \\
\hline & BH 7 & 97545.51 & & & 48.69 & 166.95 & \\
\hline & BH 9 & 88107.93 & & & 50.24 & 146.15 & \\
\hline & BH 10 & 99861.89 & & & 46.65 & 178.40 & \\
\hline & BH 15 & 124485.93 & & & 76.04 & 136.43 & \\
\hline & BH 19 & 65933.99 & & & 54.45 & 100.90 & \\
\hline & BH 21 & 120075.46 & & & 45.12 & 221.76 & \\
\hline & BH 23 & 110492.05 & & & 57.31 & 160.67 & \\
\hline & BH 27 & 115030.24 & & & 43.38 & 220.98 & \\
\hline & BH 29 & 118141.12 & & & 84.33 & 116.74 & \\
\hline & BH 31 & 176457.03 & & & 71.84 & 204.68 & \\
\hline \multirow{5}{*}{ Group 4} & BH 13 & 121154.7 & \multirow{5}{*}{416198.71} & \multirow{5}{*}{ Machine 2D } & 57.57 & 175.36 & \multirow{5}{*}{719} \\
\hline & BH 16 & 98633.09 & & & 45.41 & 180.99 & \\
\hline & BH 22 & 103436.42 & & & 55.50 & 155.31 & \\
\hline & BH 24 & 92974.5 & & & 37.28 & 207.83 & \\
\hline & BH 30 & 103416.67 & & & 39.91 & 249.33 & \\
\hline
\end{tabular}


tions of 4 types of the light duty hydraulic rock breakers are used. Table 8 shows the specifications of each machine type involved in this study for scenario 2 .

The arrangement of the rock breakers is ascending, therefore, $2 \mathrm{~A}$ has the lowest specifications and 2D has the largest capacity of the selected light duty hydraulic breakers in this paper. In general, the 4 types of the light duty hydraulic breakers used in this scenario are classified as very small to small type (Aksoy 2014). As proposed in the previous scenario, the machinery with the lowest power (2A) was employed for the excavation of the weakest rock volumes. While the strongest rock zones were excavated using the (2D) light duty breaker.

The durations and production rate are calculated in Table 9 following the productivity assessment. As expected, the calculated total working days required for each group are remarkably higher than the values in scenario 1. For Group 3 only, 1868 working days are required for the excavation of almost $42 \%$ volume of the rock mass using the $2 \mathrm{C}$ light duty rock breaker. As a comparison, the $2 \mathrm{C}$ breaker produces $27 \mathrm{hp}$, which is approx. $40 \%$ lower than the power of the $1 \mathrm{~B}$ breaker used in scenario 1 (1B produces $47 \mathrm{hp}$ ). Table 10 presents the derivation of number of light duty machines.

The derivation of number of machines for scenario 2 is presented in Table 10, based on the NBR calculations in Table 9. 4 2A-type, 4 2B-type, 6 2C- and 32D-type light duty hydraulic rock breakers are required. The machinery number does not assume maintenance or cross tasks required in the breakage of the rock mass.

Table 1o: Derivation of required number of breakers - scenario 2

\begin{tabular}{|l|l|l|l|l|}
\hline $\begin{array}{l}\text { Machine } \\
\text { Type }\end{array}$ & Group & $\begin{array}{l}\text { Total working } \\
\text { days/ Machine } \\
\text { type }\end{array}$ & $\begin{array}{l}\text { No. of machines } \\
\text { / 300 working } \\
\text { days }\end{array}$ & $\begin{array}{l}\text { Required } \\
\text { number of } \\
\text { machines }\end{array}$ \\
\hline Machine 2A & 1 & 1004 & 3.35 & 4 \\
\hline Machine 2B & 2 & 1011 & 3.77 & 4 \\
\hline Machine 2C & 3 & 1868 & 6.23 & 6 \\
\hline Machine 2D & 4 & 719 & 2.4 & 3 \\
\hline
\end{tabular}

\subsection{Comparison}

A comparison between the two scenarios is shown in Table 11. Entire machine specifications are given as well as the working durations. It is obvious that the machine working hours for light duty machines (scenario 2) is about 1.7 times scenario No. 1 as medium-duty machines. This is an important note which must be considered in both the financial and planning stages. A proper comparison shall consider the running costs and the availability of the spare parts of each type. In addition to that, a proper estimation of the working days must be conducted for the additional tasks may be required in the site, such as haulage or site arrangements for loading/ unloading of the broken rocks. Therefore a $20 \%$ increase
Table 11: Comparison between three scenarios

\begin{tabular}{|l|l|l|}
\hline Factor & Scenario 1 & Scenario 2 \\
\hline Machine class & Medium duty & Light duty \\
\hline $\begin{array}{l}\text { Power, hp } \\
{[\mathrm{KW}]}\end{array}$ & $\begin{array}{l}33-47 \\
{[24.60-35.47]}\end{array}$ & $\begin{array}{l}10-37 \\
{[7.46-27.60]}\end{array}$ \\
\hline Oil operating pressure, MPa & 16 & $10-15$ \\
\hline $\begin{array}{l}\text { Minimum required number } \\
\text { of hydraulic breakers }\end{array}$ & 10 & 17 \\
\hline Machine working hours & 36000 & 61200 \\
\hline $\begin{array}{l}\text { Recommended number of } \\
\text { breakers (+20\%)/ safety } \\
\text { factor }\end{array}$ & 12 & 20 \\
\hline
\end{tabular}

in the total number of rock breakers is assumed for both scenarios to overcome the unknown factors, as shown in Table 11.

\section{Discussion}

For assessing the number of the rock hydraulic breakers to demolish a certain volume of rock mass, it is important to obtain accurate input parameters. This could optimize the time and cost of the study. One the other hand, the results from the study will present a clear overview for the decisionmaker to determine which excavation technique, in the first place, is more visible (Drill/ Blasting or hydraulic breakers). Afterward, multiple scenarios of the hydraulic breaker types could be generated based on the different capacities of the machines, the rock mass properties, the time span, and availability of the machinery. In general, the selection of the best scenario shall be determined through comprehensive economic studies.

For explanation, the methodology could obtain an overlook for the best scenario selection, i.e.: the medium duty or the small duty rock hydraulic breaker scenarios. For a single medium duty hydraulic breaker, the average cost of the only rock mass excavation is $79500 \mathrm{EGP} /$ Month (including the fuel as well as the maintenance costs). While it costs about $55600 \mathrm{EGP} /$ month for a small duty hydraulic breaker, these costs are based on the average prices in the Egyptian market which only take the excavation process into consideration. Compared to the total number of breakers as shown in Table 11, the total expected costs for the rock mass excavation via the medium duty breakers for the entire time frame (300 workdays) is $16.6 \%$ less than the total costs for the excavation using small duty breakers. This could be an influencing factor for the selection of the best scenario. However, there are other different factors that shall be considered in a separate financial and feasibility study.

Such factors will greatly influence the work plan and the time schedule of the rock mass removal. One of the main factors is the maintenance time for the hydraulic breakers, either due to the wear of the ripping bits be- 
cause of the existence of quartz/sand materials or due to the occasional faults of the machinery in general. The second factor is the haulage cycles of the demolished rocks as a part of the rock mass removal process. Considerable time durations will be paid for the loading/ dumping stage during the work. Therefore, a separate plan for the required number of trucks and excavators shall be conducted. For the haulage process, a suitable layout of the site should be planned for the machinery flowability in the site at each stage. It is very essential to perform such a plan without intersecting with the hydraulic breakers' activities.

Another factor is the slope's instability problems, which are expected from the excessive dynamic activities by the machinery and fast rate of rock mass removal. A plan of the activities in parallel to geotechnical slope stability design must be considered prior to the work. As a result of the different factors, the total number of breakers computed by the study is highly recommended to be increased by a reasonable percentage. Generally, the rate of work is a factor of further parameters which influence the duration of the process. Thus, prior to the commencing of the rock mass demolition, a planning stage shall be established to evaluate the site works and assess the time schedule of the overlapped works.

\section{Conclusion}

The usage of the hydraulic rock breakers witnesses huge demands in the applications of the earth removal and the excavation of the rock masses. In this paper, the aim was to present a methodology that could help in the selection of the appropriate rock breaker specifications and their numbers, taking into account the geomechanical characteristics for the rock mass, the economic considerations and the time frame restrictions. The proposed methodology was applied for the excavation of a rock mass using rock breakers. To reach the design level, more than 2 and a half million cubic meters of the ground would be excavated. A site investigation plan was implemented including exploration boreholes (about 28 boreholes) and lab testing to obtain the intact rock strength (the UCS). Based on the site investigation, classification of the rock mass was conducted in which the zones with similar properties were grouped. The performance of the hydraulic breakers was calculated based on the NBR in which the rock mass properties and the horse power of the corresponding machine were applied. Based on the availability of the machinery and the economic concerns, very small to medium rock breakers were used in this paper. The time frame of the work was very restricted, and it was set as one year (approximately 300 workdays).

To test the proposed methodology, two different scenarios were applied to test the performance of the selected methodology. First, the medium duty rock breaker scenario which had an average power of 33 to $47 \mathrm{hp}$
(24.61- $35.47 \mathrm{KW)} \mathrm{would} \mathrm{require} 36000$ working hours, while the second scenario with very small to small hydraulic breakers would accomplish the removal of the rock mass in 61200 work hours. The calculated power of the light duty breakers ranged between 10 to $37 \mathrm{hp}$. Based on the timeframe, it was found that 12 medium duty machines and 20 light duty machines were required for the same rock volume. An extra $20 \%$ of the machinery numbers for both scenarios were considered due to the unknown variables that could delay the progress of the work. Finally, and as a comparison, the medium hydraulic rock breakers scenario was found $16.6 \%$ less than the total costs for the excavation using the small duty breakers. Therefore, the best decision would be to consider the medium breaker scenario for the excavation of the rock mass regardless of the other influencing factors which could be considered in a separate financial and feasibility study. Such variables and factors shall be included in the future in further studies and will be compatible with the presented methodology in this paper.

\section{References}

Aksoy, C. O. (2009): Performance prediction of impact hammers by block punch index for weak rock masses. International Journal of Rock Mechanics and Mining Science, 46(8), 1383-1388. doi: 10.1016/j.ijrmms.2009.02.008

Aksoy, C. O., Ozacar, V., Safak, S. (2013): An updated formula and method to predict the performance of impact hammers. International Journal of Rock Mechanics and Mining Science, 61(July), 289-295. doi: 10.1016/j. ijrmms.2013.02.008

Aksoy, C. O. (2014): Proposed chart for the selection of impact hammer. International Journal of Rock Mechanics and Mining Science, 46 (8): 1383-1388. doi: 10.1016/j.ijrmms. 2014.02.013

Anderson, J.T., Papineau, W. E. (1989): Rock excavation with boom mounted hydraulic hammers. In: Proceedings of the Foundation Engineering: Current Principles and pracices, Kulhawy F. (editor), vol 1. ASCE, Evanston, IL., June 2529, 418-431.

Bilgin, N., Yazici, S., Eskikaya, S. (1996): A model to predict the performance of road-headers and impact hammers in tunnel drivages. In: Proceedings of the Eurock 96 - Prediction and Performance in Rock Mechanics and Rock Engineering, Barla G. (editor), Turin, Italy, September 1996. Balkema, 715-720.

Eissa, M. A., Shawky, H., Samy, A., Khalil, M. M. H., El Malky, M. (2018): Geochemical and Isotopic Evidence of Groundwater Salinization Processes in El Dabaa Area, Northwestern Coast, Egypt. Geosciences, 8(11): 392. doi: 10.3390/geosciences8110392

El-Asmar, H. M., Wood, P. (2000): Quaternary shoreline development: the northwestern coast of Egypt. Quaternary Science Reviews, 19(11): 1137-1149. doi: 10.1016/S02773791(99)00097-9

Iphar M. (2012): ANN and ANFIS performance prediction models for hydraulic impact hammers. Tunnelling and Un- 
derground Space Technolology, 27(1), 23-29. doi: 10.1016 j.tust.2011.06.004

Jaeger, J. C. Cook, N. G. W., Zimmerman, R. W. (2007): Fundamentals of Rock Mechanics, 4th Edition. Wiley-Blackwell, ISBN: 978-0-632-05759-7

Kanji, M. A. (2014): Critical issues in soft rocks. Journal of Rock Mechanics and Geotechenical Engineering, 6(3): 186-195. doi: 10.1016/j.jrmge.2014.04.002

Kujundžić, T. Bedeković, G. Kuhinek, D., Korman, T. (2008): Impact of rock hardness on fragmentation by hydraulic hammer and crushing in jaw crusher. The Mining-Geology-Petroleum Engineering Bulletin (Rudarsko-GeološkoNaftni Zbornik), 20(1), 83-90.

Kujundžić, T., Vrkljan, D. (2014): Calculation analysis of bulldozer's productivity in gravitational transport on open pits. Tehnički vjesnik (Technical Gazette), 21(3): 517-523. ISSN 1330-3651(Print), ISSN 1848-6339 (Online)

Ocak, I., Bilgin, N. (2010): Comparative studies on the performance of a roadheader, impact hammer and drilling and blasting method in the excavation of metro station tunnels in Istanbul. Tunnelling and Underground Space Technolology. 25(2): 181-187. doi: 10.1016/j.tust.2009.11.002

Ocak, I., Seker, S. E., Rostami, J. (2018): Performance prediction of impact hammer using ensemble machine learning techniques. Tunnelling and Underground Space Technolology, 80(July), 269-276. doi: 10.1016/j.tust.2018.07.030
Pandey, V. K., Praksh, S. (2020). Optimization of efficiency of rock breaker using Geological data : Reference to Mumbai, Maharashtra, India. International Journal of Scientific Research in Engineering and Management (IJSREM), 4(6), 1-6.

Škrlec, V., Dobrilović, M., Bohanek, V. V. (2014): Teorije Loma Stijene Eksplozivom. The Mining-Geology-Petroleum Engineering Bulletin (Rudarsko-Geološko-Naftni Zbornik), 29, 57-68, (in Croatian). ISSN: 2582-3930

Sobko, B., Lozhnikov, O., Levytskyi, V., Skyba, G. (2019): Conceptual development of the to non-blasting methods for the preparation of mined rock in surface mining. The Mining-Geology-Petroleum Engineering Bulletin (Rudarsko-Geološko-Naftni Zbornik), 34(3), 21-28. doi: 10.17 794/rgn.2019.3.3

Tsiambaos, G., Saroglou, H. (2010): Excavatability assessment of rock masses using the Geological Strength Index (GSI). Bulletin of Engineering Geology and the Environment, 69(1), 13-27. doi: 10.1007/s10064-009-0235-9

Tumac, D., Hojjati, S. (2016): Predicting performance of impact hammers from rock quality designation and compressive strength properties in various rock masses. Tunnelling and Underground Space Technolology, 59, 38-47. doi: 10.1016/j.tust.2016.06.008

\section{SAŽETAK}

\section{Predviđanje svojstava hidrauličkoga razbijača stijena kod njihova iskapanja}

Potreba uporabe hidrauličkoga razbijača kod pridobivanja stijena postaje sve veća zbog očuvanja okoliša i iz ekonomskih razloga. Konvencionalne metode (poput bušenja i miniranja) imaju mnogo ograničenja s obzirom na njihov utjecaj na okoliš. Ovdje je predložena metodologija kojom se predviđaju svojstva hidrauličkoga razbijača stijena. Kao testno područje odabrano je smjestište u sjeverozapadnome Egiptu, na obali Sredozemnoga mora. Načinjena su brojna istraživanja bušenjem, a rezultati su pokazali kako je u najvećemu dijelu stijenska masa vapnenac s lećama pijeska. Temeljem istraženih svojstava stijena kartirane su kvaliteta stijenske mase i jednoosna tlačna čvrstoća. Rezultati su pomogli u zoniranju stijenske mase i svrstavanju stijena u skupine sličnih svojstava. Zbog ekonomičnosti i dostupnih strojeva istraživanje se odnosilo na razbijače vrlo maloga, maloga i srednjega kapaciteta. Za svaku vrstu izračunan je stvarni iznos lomljenja u pojedinačnim skupinama stijena. Pri tomu je izazov predstavljao vremenski ograničeno iskopavanje/lomljenje koje se obavljalo tijekom 1 godine, tj. 300 radnih dana. Razrađena su dva scenarija, prvi za strojeve srednjega i drugi za one maloga kapaciteta s potrebnim brojem jedinica i radnih dana za svaki. Prikazani algoritam može se primijeniti za druge slučajeve, s različitim svojstvima stijena, strojeva i vremenskoga okvira.

\section{Ključne riječi:}

hidraulički razbijači, iskapanje stijena, iznos lomljenja, svojstva stijena

\section{Author's contribution}

Mohamed Ismael (Ph.D., Assistant Professor, Geological Engineering and Mining) contributed to the methodology formulation, data representation, and writing and reviewing of the paper. Khaled Abdelghafar (M.Sc., Assistant Lecturer, Geological Engineering and Mining) contributed to the analysis of site investigation data, breaking scenarios calculations, and writing the paper. Mohamed Sholqamy (M.Sc., Assistant Lecturer, Geological Engineering and Mining) contributed to the analysis of site investigation data, visualization of data and result representation. Mohamed Elkarmoty (Ph.D., Assistant Professor, Geological Engineering and Mining) contributed to the conceptualization, analysis of the results, research management, and writing and reviewing the paper. 